\title{
Spice Seed Pelleting for Improved Seed Performance: A Review
}

\author{
Suryapal Singh* and Harshita Singh \\ Chaudhary Charan Singh Haryana Agricultural University, Hisar-125004, India \\ *Corresponding author
}

A B S T R A C T

\section{Keywords \\ Fennel, Spice crop, Desert, Pelleting, arid and semi arid, cash crop \\ Article Info \\ Accepted: \\ 15 April 2020 \\ Available Online: \\ 10 May 2020}

Frequent draughts are encountered due to deficient rains in desert leading to crop failure due to poor seed germination. Farmers do not have sufficient resources to bear the losses out of failure. Some techniques are effective in maintaining the germination. Fennel is the spice crop supporting the desert farmers. A sizable area is under fennel production in desert. Crop failure leads to disturb the economy of farmers. In the present review fennel seeds were pelleted to improve the germination and seed performance.

\section{Introduction}

Now a day, Global Agriculture is faced with dilemma of meeting the growing demand for seed which is most critical input of agriculture for obtaining higher yield. Quality seed production and maintaining its germination is basic need of seed programme. In this regard, seeds are treated with insecticide, fungicides, botanicals, etc. Various seed quality enhancement treatments like seed pelleting, seed priming and seed coating found very much helpful in recuperating seed quality. Seed pelleting comes under pre-sowing management in which seeds are enclosed with a small quantity of inert material using an adhesive just large enough to produce a globular unit of standard size to facilitate precision planting. The inert material creates natural water holding potential and provides nutrients to young seedlings. It is more beneficial in smaller seeds as it helps in reducing the cost and by way of saving seeds. Treatment of seeds with botanicals and other organic materials, which are economical, safe, ecofriendly and non-harmful to seed, animal and human beings can be considered as one of the best substitute to hazardous chemicals and most effective means of controlling the seed quality. The leaf powders and plant extracts have been acknowledged as main source to influence the plant performance, since the exogenous application of leaf powder of medicinal plants offer sole opportunities of 
sealing the development of plants and alter the physiological processes in the plant to increase seed quality. The botanicals of plant origin are full of anti-oxidants and useful nutrients along with antifungal and antibacterial properties. Since the loss of viability impairs the biological and planting value of seed, it is of special concern to breeders, businessmen and farmers. High relative humidity and temperature cause high moisture content in seeds resulting in low germination at the end of storage (McCormack, 2004). Inherent genetic potential, initial seed quality, environment during seed production, seed moisture content, mechanical damage, storage insects, seed borne mycoflora, seed dressing chemicals and seed treatments influences the longevity of seeds and affect their ensuing field performance. Hence, storage of seeds after harvest till next planting time is of prime importance in any successful seed production programme. Complete and appropriate knowledge regarding storage of fennel seeds under ambient environmental conditions with minimum loss in quality of seed for a period of atleast one or more seasons will be of enormous use for farming community and seed industry. There is meagre information available regarding storage life of pelleted fennel seeds. Keeping in view the above background and considering the importance of fennel in National economy, the present review was planned.

\section{Fennel}

Fennel (Foeniculum vulgare Mill.), a member of Apiaceae family, also known as Saunf or sweet cumin is an aromatic biennial plant with soft, feathery and almost hair-like foliage. It is widely cultivated crop grown extensively for its edible, strongly flavoured leaves and fruits particularly in Northern India as a rabi crop and comes up well in fairly mild climate. Indigenous to coastal areas of the Mediterranean region, it has also become widely naturalized in many parts of the world, especially in Europe and North America. Now a day, it is grown worldwide mainly in India, Russia, Mexico, Iran, China, Bulgaria, Turkey, Egypt, Morocco, Afghanistan and Canada. In India, it is cultivated in Gujarat, Rajasthan, West Bengal, Uttar Pradesh, Madhya Pradesh, Karnataka, Telangana, Punjab and Haryana. India is the largest producer and acreage holder of this crop with $53.3 \%$ of global production and covering 89.58 thousand hectares area giving production of 148.64 thousand metric tonnes (Anonymous, 2017). In Haryana, it is grown in 0.27 thousand hectares, producing 0.17 thousand metric tonnes (Anonymous, 2015). The provisional area under fennel production in India was 65810 hectare with an advance estimates of 90392 hectares with production of 103830 tonne and 157347 tonnes, respectively in year 2018-2019 with productivity of 1.58 MT per hectare in 20172018 and 1.74 MT per hectare in 2018-2019 (Indiastat 2018-2019 Source: Spice Board of India).

The entire plant of fennel is valuable. The leaves and seeds of fennel are used in many culinary traditions (Ehsanipour et al., 2012), $v i z$., leaves for garnishing, leaves and stalks in salad, its enlarged base as a vegetable, its aromatic fruits in various food preparations such as soups, meat dishes, sauces, pastries, confectionaries, pickles, and liquors, etc. The fennel seed, which is actually the dried fruit of the fennel plant, is used as a spice, either whole or ground. It is one of the five ingredients in the traditional Chinese five spice blend and is also an essential ingredient in Italian sausages. Dried fruits of fennel have scented odour with pleasant aromatic taste and therefore, used for mastication. Essential oil of fennel fruit has huge significance in food industry (Zoubiri et al., 2014). The percentage volatile oil in seed varies from 1.5 
to $3.5 \%$. Several components of the essential oil of fennel show important applications, including, limonene as solvent, wetting and dispersing agent; trans-anethole as flavouring agent in perfumery, cosmetics, soap; metylchavicol or estragole is used in perfumeries and as flavour in foods and liquors; a-pinene $\alpha$, used in manufacture of camphor, insecticides, solvents and perfume bases (Marotti et al., 1993 and Cavaleiro et al., 1993). The flowers and leaves of fennel are also used to make yellow and brown dyes (Malhotra, 2012).

Fennel seeds have been revered as one of the nine Anglo-Saxon sacred herbs for its exceptional health benefits. Also, fennel symbolizes longevity, strength, and courage. In addition to its use as medicinal values, seeds of fennel contain numerous flavonoid anti-oxidants like kaempferol, quercetin, etc. that helps in removing harmful free radicals from the body thus offering great protection from cancers, infection, aging and degenerative neurological diseases. The seeds are also a rich source of dietary fiber $(100 \mathrm{~g}$ seeds provide $39.8 \mathrm{~g}$ of fiber); a concentrated source of minerals like copper, iron, calcium, potassium, manganese, selenium, zinc, magnesium and a storehouse for many vital vitamins viz., vitamin-A, vitamin-E, vitamin$\mathrm{C}$ as well as many B-complex vitamins like thiamin, pyridoxine, riboflavin and niacin. Fennel seeds also have 14-22\% protein with 12 to $18.5 \%$ fat. Being a medicinal plant, it is used as anti-spasmodic, appetite stimulant, stomachic, diuretic, anti-inflammatory, antidiarrheic, against colic and as a lactation promoter (Marotti et al., 1993 and Cavaleiro et al., 1993).

Fennel is one of the important commercial cash crop of arid and semi arid region. Although India is the largest producer of fennel in the world, but the level of productivity of most of the spices including fennel in India is below the level as prevailing in other countries. The average productivity is only $1.66 \mathrm{MT} / \mathrm{ha}$. The lower productivity is attributed to poor seed germination rate, occasionally. Also, seed deterioration is a serious problem especially in tropical countries like India, where seed attains higher moisture at higher temperature, thereby increasing the respiration and causing loss of viability and seed deterioration. It is accordingly pertinent to find methods, which can enhance fennel seed germination and reduce the chances of seed deterioration. The good quality seed is pre-requisite to enhance the production and productivity as the good seed in good land yield abundant. Moreover; it plays a crucial role in agricultural production as well as in national economy. Hence, prior assessment of seed quality is important to grow only the quality seed in next season.

\section{Effect of organic and inorganic pelleting materials on seed quality}

Seed pelleting is the process of enclosing a seed with a small quantity of inert material to change their size and shape for improved plantability. Small, round or irregularly shaped seeds can be covered with a coating of inert material and built up into pellets containing a single seed each. The inert material creates natural holding media and provides small amount of nutrients to young seedlings (Krishnasamy, 2003). Pelleting permits the use of precision planting equipment resulting in more even distribution of small seeds along with reduction of the number of seeds required to plant a given area than the usual planting methods (Farooq et al., 2017) and also improves the chances of successful germination and seedling establishment under field conditions (Bharathi et al., 2003). Pelleting of seed with adhesive, fillers and bioactive chemicals help in achievement of desired population, which is 
the key basis for successful crop production. Nutrient pelleting, herbicide pelleting, pesticide pelleting and pelleting with botanicals and fungicides increase seed yield and quality besides offering protection to seed in field conditions. Also, storage potential of pelleted seeds is reported to be high in several crops to name a few is paprika chilli (Manjunatha, 2007) Bell Pepper (Capsicum annum L.) reported by Mehta and Verma. 2019. The research information on the effect of seed pelleting has been reviewed below under the following sub-headings:

\section{Moisture content}

No significant effect on moisture percentage among the different botanicals was observed in lentil including the control which indicated that botanicals had no effect on seed moisture percentage (Khatun et al., 2010). Whereas, Manjunatha (2007) showed that the seeds treated with polymer@ $9 \mathrm{~g} / \mathrm{kg}$ of seed and thiram @ $2 \mathrm{~g} / \mathrm{kg}$ of seed exhibited lower moisture content $(7.89 \%)$ when compared to control in chilli cv. Byadagi Kaddi.

\section{Standard germination}

The highest germination percentage of coriander was obtained in seeds pelleted with micronutrients viz., Zn, Mg and Mn @ $4 \mathrm{~g} / \mathrm{kg}$ of seeds (Fredj et al., 2013). Chaya Devi et al., (2017) recorded maximum germination (99.00\%) in seeds pelleted with $\mathrm{ZnSO}_{4}$ @ $3 \mathrm{~g} / \mathrm{kg}+$ borax @ 3g/kg + Captan @ 2.5g/kg) + Imidacloprid @ 2.5g/kg) as compared to control in French bean. Higher germination percentage was recorded with Pongamia pinnata leaf powder treatment @ $200 \mathrm{~g} / \mathrm{kg}$ by Prakash et al., (2018) in clusterbean. Pillayarasamy et al., (1973) stated that the chilli seeds of cv. K-1 treated with different fungicides (Agrosan G. N., ceresin, lime dust, captan, fyton, thiovit and TMTD at $2 \mathrm{~g} / \mathrm{kg}$ of seeds) produced higher germination over control throughout the storage period. Bujdoso, (1979) recommended cucumber seed treatment with cerasan, thiram or captan to maintain higher germination. On the other hand, Zala et al., (2016) reported that Thiram $(3 \mathrm{~g} / \mathrm{kg})+$ Imidacloprid $(600 \mathrm{~g} / \mathrm{L})$ helped to maintain higher germination at the end of eight months of storage period in chilli. Similarly, Manjunath et al., (2009) obtained superiority of seed pelleting with $\mathrm{ZnSO}_{4}(300$ $\mathrm{mg} / \mathrm{kg})+$ Captan $(2.5 \mathrm{~g} / \mathrm{kg})+$ Imidacloprid $(2.5 \mathrm{~g} / \mathrm{kg})$ with highest seed germination (94.00\%) in paprika chilli cv. Kt-PI-19. Also, Manjunatha (2007) showed that the seeds treated with polymer@ $97 \mathrm{~g} / \mathrm{kg}$ of seed and thiram@2 g/kg of seed recorded higher germination $(69.44 \%)$ as compared to control in chilli cv. Byadagi Kaddi. Higher rate of germination was recorded with the treatment of zinc + boron + arappu leaf powder followed by $\mathrm{ZnSO}_{4}$ in cowpea (Masuthi et al., 2009). The leaf powder of Annona squamosa improved germination percentage (91.67 and $95.70 \%$ ) in okra and chilli, respectively (Kumar and Muthukrishnan, 2015). Ramesh and Siddique (2015) observed that highest germination rate occurred in seeds pelleted with $\mathrm{Zn}$ and $\mathrm{GA}_{3}$. The seeds coated with polymer@ $6 \mathrm{ml} / \mathrm{kg}$ + Imidacloprid @ $1 \mathrm{ml} / \mathrm{kg}$ of seeds maintained higher germination percentage followed by seeds treated with polymer@6 ml $/ \mathrm{kg}$ + thiram @ $2 \mathrm{~g} / \mathrm{kg}$ of seeds in bhendi cv. Arka anamika (Kumar and Sakthivel, 2015).

\section{Speed of emergence}

Manjunath et al., (2009) found higher speed of germination (17.63) on pelleting with $\mathrm{ZnSO}_{4}(300 \mathrm{mg} / \mathrm{kg})+$ Captan $(2.5 \mathrm{~g} / \mathrm{kg})+$ Imidacloprid $(2.5 \mathrm{~g} / \mathrm{kg})$ in paprika chilli $\mathrm{cv}$. Kt-PI-19. Whereas, to maintain higher speed of germination in chilli at the end of eight month of storage period, pelleting with Thiram (3 g/kg) + Imidacloprid (600 g/L) proved helpful (Zala et al., 2016). Prakash et 
al., (2018) obtained maximum speed of germination by pelleting with Pongamia pinnata leaf powder in clusterbean.

\section{Seedling length}

Zala et al., (2016) observed that pelleting with Thiram (3 g/kg) + Imidacloprid (600 g/L) resulted in maximum seedling length at the end of eight month of storage period in chilli. On the other hand, Chaya Devi et al., (2017) obtained maximum seedling length $(35.20 \mathrm{~cm})$ in seeds pelleted with $\mathrm{ZnSO}_{4} @ 3 \mathrm{~g} / \mathrm{kg}+$ Borax @3g/kg + Captan @ 2.5g/kg + Imidacloprid @ 2.5g/kg as compared to control in French bean.

\section{Seedling dry weight}

Maximum seedling dry weight $(248.83 \mathrm{mg})$ was obtained with $\mathrm{ZnSO}_{4} @ 3 \mathrm{~g} / \mathrm{kg}+$ borax @ 3g/kg+Captan@2.5g/kg + Imidacloprid @ $2.5 \mathrm{~g} / \mathrm{kg}$ by Chaya Devi et al., (2017) in French bean. Whereas, in cowpea, Masuthi et al., (2009) recorded higher seedling dry weight $(0.595 \mathrm{~g})$ by pelleting with $\mathrm{ZnSO}_{4}$. Zala et al., (2016) found that pelleting with Thiram (3 g/kg) + Imidacloprid $(600 \mathrm{~g} / \mathrm{L})$ helped getting maximum seedling dry weight at the end of eight month of storage period in chilli. Also, seed pelleting with $\mathrm{ZnSO}_{4}(300$ $\mathrm{mg} / \mathrm{kg})+$ Captan $(2.5 \mathrm{~g} / \mathrm{kg})+$ Imidacloprid $(2.5 \mathrm{~g} / \mathrm{kg})$ resulted in maximum seedling dry weight $(43.94 \mathrm{mg})$ in paprika chilli cv. Kt-PI19 by Manjunath et al., (2009). Also, Manjunatha (2007) showed that the seeds treated with polymer @ $7 \mathrm{~g} / \mathrm{kg}$ of seed and thiram @ $2 \mathrm{~g} / \mathrm{kg}$ of seed recorded higher seedling dry weight $(38.88 \mathrm{mg} / 10$ seedlings) in chilli cv. Byadagi Kaddi as compared to control. The seeds of bhendi cv. Arka Anamika coated with polymer@6 ml/kg + Imidacloprid @ $1 \mathrm{ml} / \mathrm{kg}$ of seeds exhibited maximum seedling dry weight followed by seeds treated with polymer @ $6 \mathrm{ml} / \mathrm{kg}+$ thiram @ 2 g/kg of seeds as observed by Kumar and Sakthivel (2015).

\section{Vigour indices}

In French bean, Chaya Devi et al., (2017) obtained maximum seedling vigour index-I (3484) and seedling vigour index-II (2463) in seeds pelleted with $\mathrm{ZnSO}_{4} @ 3 \mathrm{~g} / \mathrm{kg}+$ borax @ $3 \mathrm{~g} / \mathrm{kg}+$ Captan $(2.5 \mathrm{~g} / \mathrm{kg})+$ Imidacloprid $(2.5 \mathrm{~g} / \mathrm{kg})$ as compared to control. Zala et al., (2016) on treatment with Thiram $(3 \mathrm{~g} / \mathrm{kg})+$ Imidacloprid (600 g/L) noted maximum seed vigour index (length) and seed vigour index (mass) at the end of eight month of storage period in chilli. Whereas, in paprika chilli cv. Kt-PI-19 Manjunath et al., (2009) obtained maximum vigour index (17.37) by pelleting the seeds with $\mathrm{ZnSO}_{4}(300 \mathrm{mg} / \mathrm{kg})+$ Captan $(2.5 \mathrm{~g} / \mathrm{kg})+$ Imidacloprid $(2.5 \mathrm{~g} / \mathrm{kg})$. The leaf powder of Annona squamosa improved vigor index (1054 and 1713.0) in okra and chilli, respectively and can be commercially utilized for enhancing their seed quality (Kumar and Muthukrishnan, 2015). Masuthi et al., (2009) recorded higher vigour index (4277) on pelleting with $\mathrm{ZnSO}_{4}$ in cowpea. Prakash et $a l$. , (2018) noticed an increase in vigour index with more pronounced effect by Pongamia pinnata leaf powder in clusterbean. Higher seedling vigour index have been obtained by (Kumar and Sakthivel, 2015) in bhendi cv. Arka Anamika seeds coated with polymer @ $6 \mathrm{ml} / \mathrm{kg}$ + Imidacloprid @ $1 \mathrm{ml} / \mathrm{kg}$ followed by seeds treated with polymer @6 ml/kg + thiram @ 2 g/kg. While, Manjunatha (2007) showed that the seeds treated with polymer@ $7 \mathrm{~g} / \mathrm{kg}$ of seed and thiram @ $2 \mathrm{~g} / \mathrm{kg}$ of seed, recorded higher vigour index (991) as compared to control in chilli cv. Byadagi Kaddi.

\section{Electrical conductivity}

Superiority of seed pelleting with $\mathrm{ZnSO}_{4}(300$ $\mathrm{mg} / \mathrm{kg})+$ Captan $(2.5 \mathrm{~g} / \mathrm{kg})+$ Imidacloprid $(2.5 \mathrm{~g} / \mathrm{kg})$ was reported by Manjunath et al., (2009), which depicted lower electrical conductivity $(0.365 \mathrm{dS} / \mathrm{m})$ than the other treatments in paprika chilli cv. Kt-PI-19. 
Similar results were obtained by Manjunatha (2007) in chilli cv. Byadagi Kaddi, where seeds treated with polymer @ $7 \mathrm{~g} / \mathrm{kg}$ of seed and thiram @2 g/kg of seed exhibited lower electrical conductivity $(2.023 \mathrm{dS} / \mathrm{m})$ as compared to control. Ramesh and Siddique (2015) observed that seeds pelleted with $\mathrm{Zn}$ and $\mathrm{GA}_{3}$ exhibited lowest leakage of solutes with an electrical conductivity (EC) of 8 $\mathrm{dS} / \mathrm{m}^{2}$, which was lower than that of control $\left(16 \mathrm{dS} / \mathrm{m}^{2}\right)$. Electrical conductivity differed significantly due to seed pelleting and lower EC was observed in $\mathrm{ZnSO}_{4}(1.01 \mathrm{dS} / \mathrm{m})$ pelleted treatment in cowpea (Masuthi et al., 2009). Chaya Devi et al., (2017) noticed lower electrical conductivity $(1.16 \mathrm{dS} / \mathrm{cm})$ in seeds pelleted with $\mathrm{ZnSO}_{4}$ @ 3g/kg + borax @ 3g/kg + Captan @ 2.5g/kg + Imidacloprid ( ) $2.5 \mathrm{~g} / \mathrm{kg}$ compared to control in french bean.

\section{Biochemical parameters}

Total dehydrogenase activity (2.77) was found maximum by Chaya Devi et al., (2017) in french bean seeds pelleted with $\mathrm{ZnSO}_{4} @$ 3g/kg + Borax@3g/kg + Captan@2.5g/kg + Imidacloprid @2.5g/kg as compared to control.

In conclusion, pelleting of Fennel seeds with organic and inorganic pelleting materials enhances the seed quality as measured by seed emergence, seedling length, seedling dry weight with all electrical conductivity and hormonal parameters. The seed pelleting in Fennel may improve the performance of seed germination in arid and semi arid region, leading to savings on seed to the farmers.

\section{References}

Anonymous, 2015. Spice Board of India, Ministry of Agriculture and Farmers Welfare, Government of India.

Anonymous, 2017. Spice Board of India, Ministry of Agriculture and Farmers Welfare,
Government of India.

Bharathi, A., Nateshan, P., Vanangamudi, K., Sherin, P.S., Ramya, M. and Thangavel, P., 2003. Conceptual and utility differences among seed enhancement technologies viz., seed pelleting, seed coating and seed colouring. ICAR short course on seed hardening and pelleting technologies for rainfed/garden hand ecosystems, May 27 to June 5, Tamil Nadu Agricultural University, Coimbatore, p.131.

Bujdoso, G., 1979. Effect of pre-storage treatment on cucumber seed germination. Zoldesegtermesztesi Katato Intext Bulletin, 13: 49-54.

Cavaleiro, C.M.F., Roque, O., Proencada, L. and Cunha, A., 1993. Contribution for the characterization of portuguese fennel chemotypes. Journal of Essential Oil Research, 5:223-225.

Chaya Devi, K., Balakrishna, P. and Chandraprakash, J., 2017. Studies on the Influence of seed Pelleting on Seed Yield and Quality in French Bean (Phaseolus vulgaris L.) cv. "Arka Anoop". International Journal of Current Microbiology and Applied Sciences, 6(5): 1912-1918.

Ehsanipour, A., Razmjoo, J. and Zeinali, H., 2012. Effect of nitrogen rates on yield and quality of fennel (Foeniculum vulgare Mill.) accessions. Industrial Crops Products, 35(1): 121-125.

Farooq, M., Wahid, A. and Siddique, K.H., 2017. Micronutrient application through seed treatments: a review. Journal of Soil Science and Plant Nutrition, 12(1):125-142.

Fredj, M.B., Zhani, K., Hannachi, C., Mehwachi, T., 2013. Effect of NaCI priming on seed germination of four coriander cultivars (Coriandrum sativum). Eurasian Journal of Biosciences, 7: 21-29.

Khatun, A., Bhuiyan, M. A. H., Kabir, G. and Haque, A. K. M. M., 2010. Effect of different botanicals on the seed quality of lentil during storage. Bulletin of the Institute of Tropical Agriculture, Kyushu University, 33(1): 19-26.

Krishnasamy, V., 2003. Seed pelleting principles and practices, ICAR Short Course on Seed Hardening and Pelleting Technologies for 
Rainfed. Garden Land Ecosystems, Tamil Nadu Agricultural University, Coimbatore. pp.96.

Kumar, S.E. and Sakthivel, T., 2015. Effect of polymer seed coating on storability of bhendi (Abelmoschus esculentus L.) cv. Arka Anamika. Journal of Emerging Technologies and Innovative Research, 2(7):231-250.

Kumar, S.R. and Muthukrishnan, R., 2015. Impact of organic seed pelleting on seed germination and seedling development in okra and chilli pepper. International Journal of Science and Nature, 6:480-483.

Malhotra, S.K., 2012. Fennel and fennel seed. In: Peter KV (Ed.), Handbook of Herbs and Spices, ( $2^{\text {nd }}$ edition), Volume 2 , A volume in Woodhead Publishing Series in Food Science, Technology and Nutrition, UK, pp. 275-302.

Manjunath, S.N., Deshpande, V.K., Sridevi, O., Uppar, D.S., Babalad, H.B. and Rao, M.S.L., 2009. Influence of seed pelleting on crop growth, seed yield and quality of paprika chilli (Capsicum annuum L.) Karnataka Journal of Agricultural Sciences, 22:762-64.

Manjunatha, S. N., 2007. Polymer coating on storability of chilli (Capsicum annuum L.) seeds. M.Sc. (Agri.) Thesis, University of Agricultural Sciences, Dharwad, India.

Marotti, M., Dellacecca, V., Piccaglia, R., Giovanelli, E., Palevitch, D. and Simon, J.E., 1993. Agronomic and chemical evaluation of three varieties of Foeniculum vulgare Mill. Acta Horticulturae, 331:6369.

Masuthi, D.K.A., Vyakaranahal, B. S. and
Deshpande, V. K., 2009. Influence of pelleting with micronutrients and botanical on growth, seed yield and quality of vegetable cowpea. Karnataka Journal of Agricultural Sciences, 22(4): 898-900.

Mehta, D K and Verma, R.2019. Effect of seed pelleting on seed quality parameters of Bell Pepper(Capsicum annum L.) under laboratory and nursery conditions. International Journal of Microbiology Research, 11(1): 1452-1454

Pillayarasamy, K., Sivaprakasam, K. and Subbaraja, K. T., 1973. Effect of fungicides on the viability of chilli seeds. Madras Agricultural Journal, 60: 618.

Prakash, M., Pallavamallan, S., Sathiyanarayanan, G. and Rameshkumar, S., 2018. Effect of seed pelleting with botanicals on germination and seedling growth of clusterbean under induced saline conditions. Legume Research, DOI: 10.18805/LR-4060

Ramesh, M. and Siddique, K.H., 2015. Seed pelleting with micronutrient and growth regulators: a bird view. Journal of Phyto Physiology, 10(5): 25-42.

Zala, I.M., Bhatiya, V.J., Chormule, S.R. and Vaja, A.D., 2016. Effect of organic and inorganic pelleting materials and storage environment on viability and vigour of chilli seeds during storages. International of Agriculture Sciences, 8(51): 2329-2331.

Zoubiri, S., Baaliouamer, A., Seba, N. and Chamouni, N., 2014. Chemical composition and larvicidal activity of Algerian Foeniculum vulgare seed essential oil. Arabian Journal of Chemistry, 7(4): 480485 .

\section{How to cite this article:}

Suryapal Singh and Harshita Singh. 2020. Spice Seed Pelleting for Improved Seed Performance: A Review. Int.J.Curr.Microbiol.App.Sci. 9(05): 1879-1885. doi: https://doi.org/10.20546/ijcmas.2020.905.213 